\title{
THE ARCHAIC BIOGRAPHY OF HOMER
}

\section{Maarit Kivilo}

Seven biographies of Homer and the story of his competing with Hesiod have reached the modern times. ${ }^{1}$ The material was compiled in the Hellenistic and Roman times, but it still contains a lot of data from the archaic and classical periods. ${ }^{2}$ The knowledge of Homer's parents (Meles, Maion, Cretheis) has already come from Eugaion, Asius, Pherecydes, Hellanicus, Damastes and Stesimbrotus ${ }^{3}$; his name (Homeros, Melesigenes) has been mentioned by Callinus, Archilochus, Asius, Eugaion and Critias ${ }^{4}$; the data on his birthplace (Smyrna, Chios, Ios) can be found from Anaximenes, Pindar, Bacchylides, Stesimbrotus and Critias ${ }^{5}$; his blindness from Semonides/Simonides and Thucydides"; the "riddle of lice", which is closely connected to the death of Homer, was known already to Heraclitus ${ }^{7}$; the knowledge of the contest with Hesiod may have even come from Lesches ${ }^{8}$.

The awareness of the details of Homer's life at the end of the 6th and the beginning of the 5th century may well serve as an indication to an early source, written close to the end of the 6th century and commonly known and available to the later authors.

\footnotetext{
${ }^{1}$ See Homeri opera, rec. Thomas W. Allen. Tomus V hymnos cyclum fragmenta Margiten Batrachomyomachiam vitas continens, Oxonii 1912; ВІОГРАФОI. Vitarum scriptores Graeci minores, edidit Antonius Westermann, Brunsvigae, 1845, 1-45; Vitae Homeri et Hesiodi in usum scholarum, edidit Udalricus de Wilamowitz-Moellendorff, Berlin 1929.

${ }_{2}^{2}$ Pace U. v. Wilamowitz-Möllendorff, Die Ilias und Homer, 1916; and F. Jacoby, Homerisches. Der Bios und die Person, 1933. After having reviewed the tradition I reached the conclusion that the knowledge of almost all the most essential points in the tradition can be traced back to the end of the 6th or the beginning of the 5th century.

${ }^{3}$ Eugaion FHG II 16; Asius PLG ${ }^{4}$ II: 23; Procl. Chrest. p. 99 f. Allen; Stesimbr. FHG II 58 fr. 18.

${ }^{4}$ Call. fr. 10 G-P; Archil. fr. 201 West; Eugaion FHG II 16; Asius PLG ${ }^{4}$ II: 23; Critias FHG II 70 fr. 11.

${ }^{5}$ Anaxim.: Vita. VI: 5; Pind. Nem. 2.1, Bacchylides fr. 48 Bl, Eustath. in Iliadem 4.17; Vita VI: 5f.; Critias FHG II $70 \mathrm{fr} .11$. The Anaximenes mentioned in Vita VI is usually considered to be the rhetor and historian from Lampsacus, whose name was also Anaximenes and who lived in the 4th century B.C. (FGrHist. 72 F 30 = Vita VI: 5f.; see Allen 1912: 250, J. G. Welcker, Der Epische Cyclus oder die Homerischen Dichter, 1865: 164 n. 246). Still, I do not see any reason why Anaximenes mentioned above could not be Anaximenes from Miletus, the philosopher who lived in the last third of the 6th century. This opinion is supported by the fact that Anaximenes is mentioned in Vita VI together with Damastes and Pindar, who lived only some time later than he did.

${ }^{6}$ Semonides fr. 29 Diehl $=$ Simonides fr. 8 West; Thucydides 3.104.4 f. About the fact whether the fragment belongs to Semonides of Amorgos or Simonides of Ceos, see Th. Bergk PLG ${ }^{4}$ II: 441, III: 1146; M. L. West, Simonides redivivus, in: ZPE 98 (1993): 1-14; C. M. Bowra, Homer, in: The Oxford Classical Dictionary, 1970: 524.

${ }^{7}$ Heracl. 22 B 56 DK.

${ }^{8}$ Plut. Sept. sap. conv. 153 F. Cf. Th. Allen, Homer. The Origins and the Transmission, 1924: 26; 1912: 136, 218; 1924: 25 f.; J. G. Welcker, Der Epische Cyclus oder die Homerischen Dichter, 1865: 251; Fr. Nietzsche, Der Florentische Traktat über Homer und Hesiod, ihr Geschlecht und ihren Wettkampf, in: Rh. Mus. (1870) 25: 533; contra: M. L. West, The Contest of Homer and Hesiod, in: CQ (1967) 61: 138, 439; Wilamowitz, op. cit. p. 405 n. 2 and G. S. Kirk, The Michigan AlcidamasPapyrus; Heraclitus fr. 56 D; The Riddle of the Lice, in: CQ (1950) 44. 3, 4: 150 n. 1. See also N. Richardson, The Contest of Homer and Hesiod and Alcidamas' Mouseion, in: CQ (1981) 31: 2: "The idea of a rhapsodic contest in бoфí $\alpha$ as an alternative to athletic contests (cf. Certamen $64 \mathrm{ff}$.), is appropriate to the age of Xenophanes."
} 
Besides, at the end of the 6th century an understanding about the authorship of archaic epics began to take a more or less clear form. Before that time Homer was considered to have composed almost all the epics. ${ }^{9}$ Presumably, the change in opinions took place at the end of the 6th century as the outcome of the so-called Athenian recension. ${ }^{10}$ From that time onwards the point of view that only the Iliad, the Odyssey and the Margites could be ascribed to Homer became more and more commonly recognized. ${ }^{11}$

The change could be brought about by the order of Solon/Peisistratids to recite exclusively the Iliad and the Odyssey as the epics composed by Homer at the Great Panathenaea, thus affirming the authorship of Homer as regards the epics concerned. ${ }^{12}$

Thus the discussions about which of the epics might have been composed by Homer, as well as the considerations about his person and life seem to have taken place simultaneously, at the end of the 6th century. The increased interest in the person of the poet gives reason to assume that something in connection with those discussions might have also been put down at that time. Consequently the hypothetical written source of the later biographies of Homer may originate at the latest from the time of Peisistratids, i.e. from the last quarter of the 6th century.

At the end of the 6th century, Theagenes from the city of Rhegium, South-Italy, became interested in the issues connected with Homer. ${ }^{13}$ He recited Homeric poems, ${ }^{14}$ interpreted them in a new, "allegorical" way, studied the grammar of Homer ${ }^{15}$ and was said to be one of the first to write about "his poetry, descent and time" ${ }^{16}$ the work which most probably contained also the data on Homer's biography.

It all refers to thorough studies on Homer, evidently brought about by the increase of general interest in the person of the poet at the end of the archaic period. This is also testified by the existence of criticism on Homer at that period ${ }^{17}$ Xenophanes directed his criticism towards the anthropomorphic gods created by Homer (and Hesiod), ${ }^{18}$ Heraclitus from Ephesus criticised Homer's view of life ${ }^{19}$ as well as the rhapsodes who recited his poetry. ${ }^{20}$

\footnotetext{
${ }^{9}$ Callinus attributed the Thebais to Homer (fr. 6), and it could also be the work, which Cleisthenes ascribed to Homer (Hdt. 5.67); the Margites was ascribed to Homer by Archilochus (fr. 201 West); the Iliad and the Odyssey by Solon, Peisistratus and Hipparchus (Hereas FGrHist 426.7, Ael. V.H. 13.14, Strab. 9.1.10, Quint. 11.40.)

${ }^{10}$ Athenian reduction: Hereas (426 F 7); Dieuchidas (485 F 6); Plat. Hipp. 228 B; Plut. Lyc. 4 D; Arist. fr. 611.10 Rose; Heliodorus, schol. Dion. Thrax (Allen 1924, p. 231); Ael. V.H. 13.14; Paus. 7.26.13; Cic. de Or. 3.34.137; Gellius N.A. 7.17.1; Tzetzes (Allen, 1924: 233).

${ }^{11}$ Only Hellanicus (FHG I 46 fr. 7) did not ascribe the Odyssey to Homer.

${ }^{12}$ Although, relying on Thucydides and Herodotus, the authorship of different parts of the Epic Cycle was not clear even in the 5th century. Herodotus, with hesitation, agreed to the assumption that Homer might be the author of the Epigonoi (4.32), but certainly did not link him to the Cypria (2.117). Thucydides (3.104) ascribed also the Hymn to Apollo to Homer.

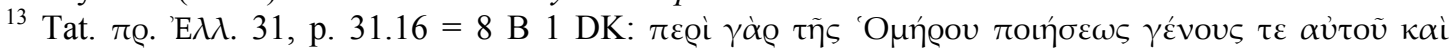

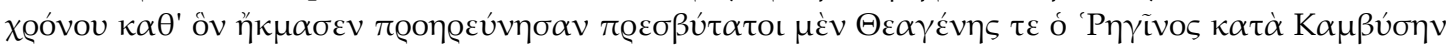

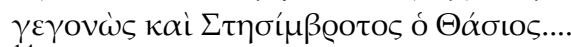

${ }^{14}$ From him we know the different reading on A 381, see Schol. Hom. A $=72$ B 3 DK.

${ }^{15}$ Schol. Dion. Thrac. p. $164.23=72$ B 1a DK. Although the term $\alpha \lambda \lambda \eta \gamma \gamma$ oqí $\alpha$ is Hellenistic, there must have been something in the interpretation of Homer by Theagenes, which later gave reason to consider it allegorical. The description of gods by Pherecydes of Syros is also allegorical in its essence.

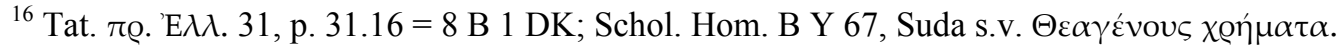

${ }^{17}$ According to Diogenes Laertius (II. 46) Homer was criticized during his lifetime by Syagros. It is not known what the criticism contained.

${ }^{18}$ Xenoph. 21 B 11 DK; Diog. L. IX 18 and II 46, Sext. Emp. IX 431.

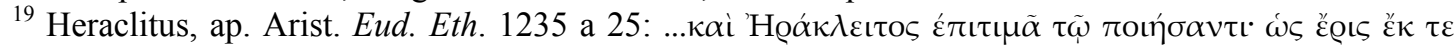


The end of the archaic period is also the beginning of Greek prose literature dealing with past: Hecataeus of Miletus, known as the first Greek logograph and prose writer, wrote about geography and history of Greece. The events of the distant past caught interest also in the orphic circles, the earliest texts of which are dated back to the end of the archaic period. One of the orphics, Onomacritus of Athens, ${ }^{21}$ who was working in the court of Peisistratus and his sons, was later considered one of the composers of

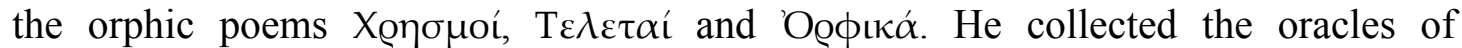
Musaeus $^{22}$ and was said to have participated together with Orpheus of Croton and Zophyrus of Heraclea in the reduction of Homeric poetry. ${ }^{23}$ It demonstrates that the poetry of Homer, Orpheus and Musaeus was thoroughly examined and issued simultaneously. ${ }^{24}$ Pythagoreans were also involved in the process. Pythagoras himself $^{25}$ and his disciples ${ }^{26}$ were considered the authors of orphic poems. Pherecydes, the teacher of Pythagoras, was known as the collector of the poetry of Orpheus, ${ }^{27}$ while the other teacher of Pythagoras, Hermodamas, belonged to the Kreophylidai, who were believed to be the preservers and also the performers of Homeric poems. ${ }^{28}$ One may think that Hermodamas was directly involved in recitation, investigation and preservation of Homeric poetry and in all likelihood shared his knowledge of Homer also with his students.

At the end of the 6th century, orphism and Pythagoreanism spread into Italy. Pythagoras, escaping from the tyranny of Polycrates, left Samos ${ }^{29}$ and after long wanderings arrived at Croton, South-Italy. ${ }^{30} \mathrm{He}$ must have brought along an interest in both the person and the poetry of Homer and could have carried also the knowledge of recension of Homeric poetry accomplished in Athens.

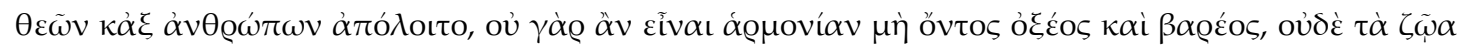

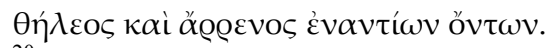

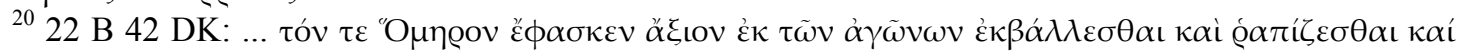
Aexíloxov ópoíws. For the opinion on the idea of the fragment see G. Nagy, Early Greek Views of poets and Poetry, in: KENNEDY (1989) p. 38, and B. Graziosi, Cambridge dissertation Inventing the Poet: a study of the early reception of the Homeric poems, p. 21: the rhapsodes should not be allowed to perform any poems of Homer and Archilochus on poetic contests.

${ }^{21}$ Suda s.v. 'Oeфeús.

${ }^{22}$ Hdt. 7.6. Onomacritus was said to have interpolated his own verses into the poetry of Musaeus and Homer (see also schol. ad Od. 11.604).

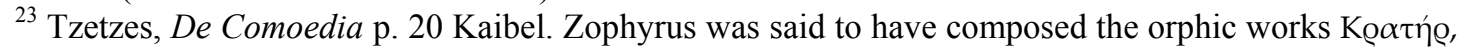

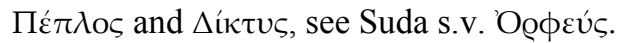

${ }^{24}$ See M. L. West, The Orphic Poems (1983) p. 250.

${ }^{25}$ Ion of Chios Triagmoi 36 B 2 DK

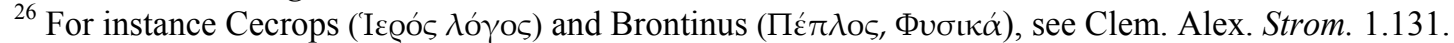

${ }^{27}$ See M. L. West 1983 (op. cit): 20 and n. 46.

${ }^{28}$ Neanthes, FGrHist. 84 F $29=$ Porph. Vita Pyth. 1. See W. Burkert, Lore and Science in Ancient Pythagoreanism, 1972 p. 102. Kreophylidai were either the descendants of Creophylus who was a friend (or son-in-law) of Homer, or a guild of rhapsodes founded by Creophylus on Samos. For Kreophylidai see W. Burkert, Die Leistung eines Kreophylos, in: Mus. Helv. 29 (1972). According to Aristotle, Lycurgus, the Spartan lawgiver, was said to have received poems of Homer from the Kreophylidai and brought them to Greece (fr. 611.10 R.); Ephorus, who considered Lycurgus several generations older, assumed that he might have received the poems directly from Homer during their meeting on Chios (fr. 164).

${ }^{29}$ Aristox. fr. $16 \mathrm{~W}$.

${ }^{30}$ Alcidamas in Arist. Rhet. $1398610 \mathrm{f}$. 
Heroic epic was definitely known in South-Italy before the arrival of Pythagoras. ${ }^{31}$ It was known even so well that it had given rise to a new genre: mythic-epic narrative in a lyric form. Epic songs started to be presented probably in a more variable metrical form, the presentations became more emotional and were accompanied by music and dance. $^{32}$ The most well known performer of melic epic in South-Italy was Stesichorus, who was considered son of Hesiod, probably on the grounds of his popularity and close contacts with epics. ${ }^{33}$ Stesichorus may have been close to Pythagoreans as well. ${ }^{34}$ There were also other reciters who presented heroic epics in a new way, for instance Xanthus, Xenocritus of Locris and Ibycus of Rhegium, who later settled on Samos; $;^{35}$ and also Xenophanes, philosopher and a critic of Homer, who arrived in South-Italy at the end of the 6th century, settled down in Sicily and was probably one of the reciters of Homeric poetry.

The new genre gained popularity and this might have paved the way for the comeback of pure epic narrative as well as the appearance of rhapsodes, who began to perform Homeric poetry without any musical accompaniment or dance. ${ }^{36}$ Rhapsodic contests started to be arranged. One of the first probably took place in Syracuse (69. Ol. or 504/1 BC) and the epic poems were recited there by the rhapsode Cynaithus of Chios. He is known to have interpolated his own verses into the poems of Homer, ${ }^{37}$ which proves his deep knowledge of him ${ }^{38}$. He may have been the first in Sicily to present the Homeric texts revised in Athens, i.e. the Iliad and the Odyssey in the form more or less similar to the one we are familiar with today. ${ }^{39}$ Thus Cynaithus from Chios, the island of Homeridai, was active in Sicily at the end of the 6th century. It is most possible that his wanderings took him also to other places in South-Italy and in addition to performing his own songs as well as the poetry of Homer, he told the stories about the life of the poet.

Hence everything seems to support the assumption that there really existed great interest in Homer both in Greece and in South-Italy at the end of the 6th century. His poetry was recited and interpreted, criticized and studied. His biography was known in its general points. There also existed a more or less formed opinion on the authorship of Homeric epics. Rhapsodes kept reciting them both in Italy and in Greece, at the same time probably spreading the knowledge of the details of the poet's life. At the same time there appeared the work of Theagenes on Homer's "poetry, descent and time." It must have contained a lot of data on Homer, which was commonly known and accepted at that time. In all likelihood it contained the most part of the points regarded as canonical later on. Hence it must have been the work, which already at the end of the 6th century presented a coherent summary of the biography of Homer. There might have existed other biographies as well (perhaps

\footnotetext{
${ }^{31}$ The cup of Nestor from about the year 720 BC, with an inscription referring to the Iliad (Il. 11.632635 ) or to the epic tradition in general, was found on the island of Ischia, near the coast of Italy.

${ }^{32}$ W. Burkert, The Making of Homer in the 6th Century B.C.: Rhapsodes versus Stesichoros, in: Papers on Amasis Painter and his World, 1987, p. 51f.

${ }^{33}$ Arist. fr. 524 R.

34 Arist. Rhet. 1395 a 1, Iambl. Vita Pyth. 267; see West, Stesichorus, in: CQ 21 (1971) p. 302 f., F. Buffière, Les Mythes d'Homère (1973) p. 103.

${ }^{35}$ M. L. West (1971) p. 313; D. A. Campbell, Greek Lyric Poetry (1982) p. XVIII.

${ }^{36}$ Burkert, 1987 p. 53.

${ }^{37}$ Schol. Pind. Nem. 2.1.

${ }^{38}$ Cynaithus might have won the contest by performing the Hymn to Apollo, which he himself had composed and then attributed to Homer. See W. Burkert 1979, Kynaithos, Polycrates, and the Homeric Hymn to Apollo, in: ARKTOUROS, p. 54 f., and West, 1975 p. 165 f.

${ }^{39}$ M. Skafte Jensen, The Homeric Question and the Oral-Formulaic Theory (1980) p. 154.
} 
even earlier ones), ${ }^{40}$ which the authors of the later times could have used as the sources of information. There are, unfortunately, none left.

\footnotetext{
${ }^{40}$ According to Allen $(1924$, p. 26) the biographical poem about Homer and his contest with Hesiod might have been composed already by Lesches (the 7th century BC; contra: see West, 1967, p. 439); and [Hesiod] fr. $357 \mathrm{M}-\mathrm{W}$, according to which the contest had taken place in Delos, originates from a very early biography (of Hesiod) written by an author of Hesiodic school.
} 